\title{
Density of Freshly Fallen Snow In the Central Rocky Mountains
}

Arthur Judson

Nolan Doesken

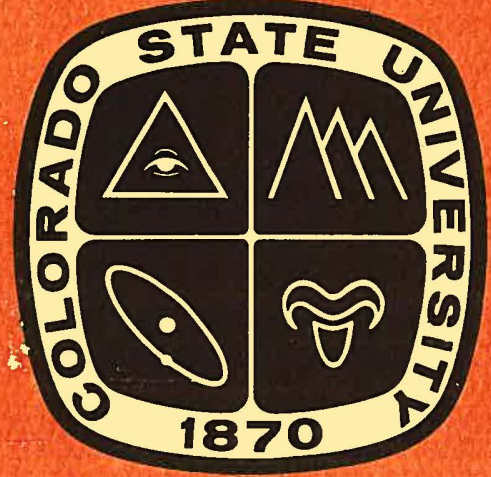

Climatology Report No. 99-2

DEPARTMENT OF ATMOSPHERIC SCIENCE COLORADO STATE UNIVERSITY

FORT COLLINS, COLORADO 


\title{
Density of Freshly Fallen Snow In the Central Rocky Mountains
}

\author{
Arthur Judson \\ (retired, U.S. Forest Service) \\ Nolan Doesken \\ Colorado Climate Center \\ Atmospheric Science Department \\ Colorado State University \\ Fort Collins, CO 80523-1371
}

Funding provided by Contract \#1425-97-PG-81-65337

U.S. Department of Interior Bureau of Reclamation Denver Federal Center Denver, Colorado

September 1999

Climatology Report No. 99-2

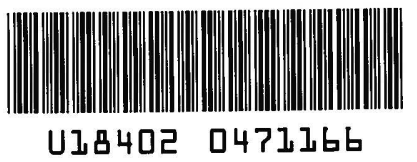




\title{
Density of Freshly Fallen Snow in the Central Rocky Mountains
}

\begin{abstract}
$\underline{\text { Abstract }}$
New snow density distributions are presented for six measurement sites in the mountains of Colorado and Wyoming. Densities were computed from daily measurements of new snow depth and water-equivalent from snow board cores. All data were measured in wind-protected forest sites. Observed densities of freshly fallen snow ranged from $10 \mathrm{~kg} \mathrm{~m}^{-3}$ to $257 \mathrm{~kg} \mathrm{~m}^{-3}$. Average densities at each site based on four years of daily observations ranged from 72 to $103 \mathrm{~kg}$ $\mathrm{m}^{-3}$. Seventy-two percent of all daily densities fell between 50 and $100 \mathrm{~kg} \mathrm{~m}^{-3}$. Approximately $5 \%$ of all daily snows had densities below $40 \mathrm{~kg} \mathrm{~m}^{-3}$. The highest frequency of low densities occurred at Steamboat Springs and Dry Lake. Density distributions from a few other sites in the U.S. appear very similar to these Rocky Mountain distributions except that the frequency of densities greater than $100 \mathrm{~kg} \mathrm{~m}^{-3}$ are significantly greater west of Colorado and Wyoming. The relationship between air temperature and new snow density exhibited a decline of density with temperature but an $\mathrm{r}$ value of only 0.52 . No obvious reversal toward higher densities occurred at cold temperatures as some previous studies have reported. No clear relationship was found between snow density and the depth of new snowfalls. Correlations of daily densities between measurement sites decreased rapidly with increasing distance between sites. New snow densities are strongly influenced by orography which contributes to large density differences over short distances.
\end{abstract}




\section{Table of Contents}

\section{Page}

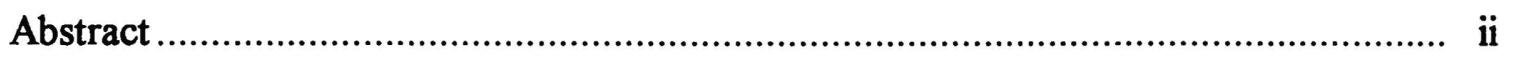

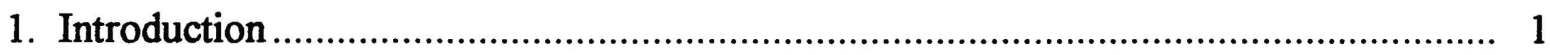

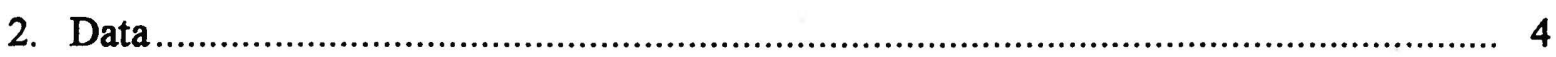

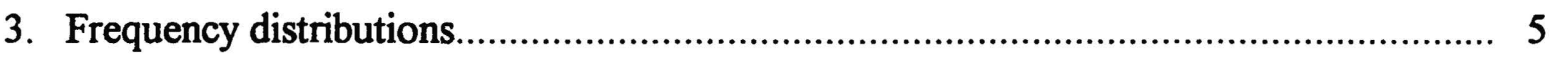

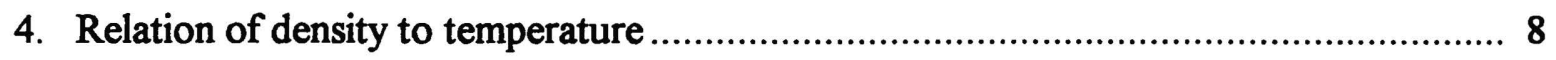

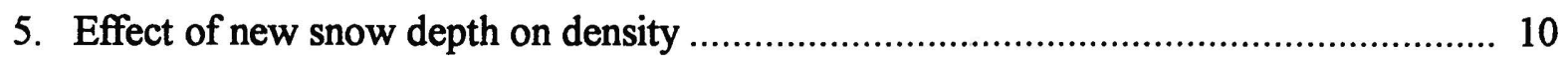

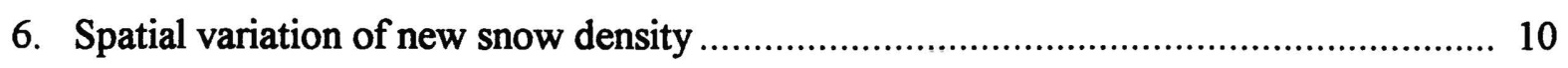

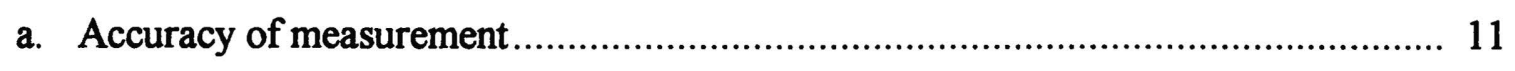

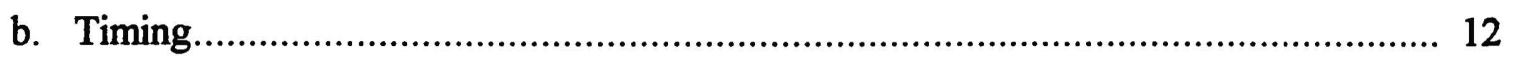

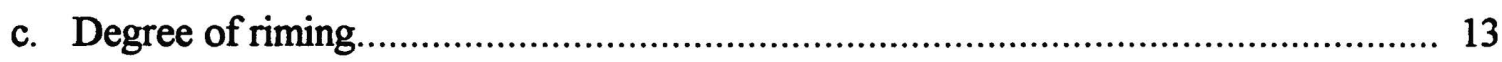

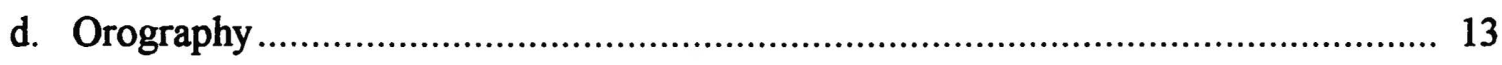

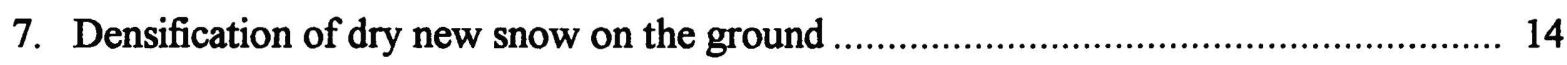

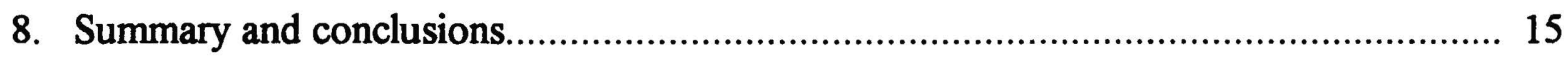

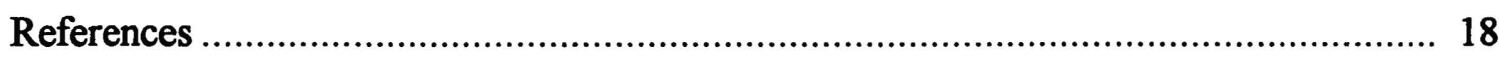

Table 1. Site information for snow density data collection sites in Colorado

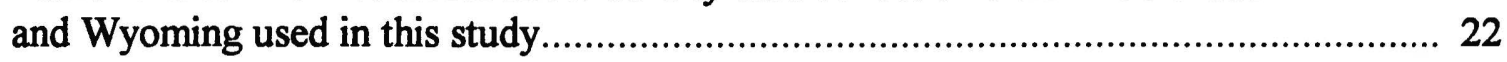

Table 2. Comparative snow density characteristics................................................ 23

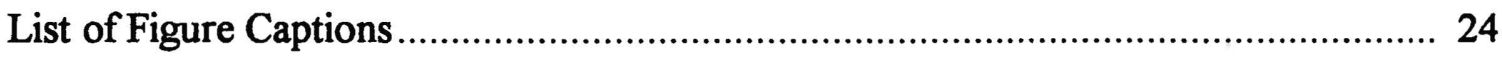




\section{Density of Freshly Fallen Snow in the Central Rocky Mountains}

\section{Introduction}

Snow density is the single most important physical property of snow. It establishes the relationship between snow and its water content, correlates with snow strength and ease of removal, and is an input parameter in a snow accumulation algorithm used to estimate new snow depths with the NEXRAD WSR-88D radar (Super and Holroyd 1997). It is used to forecast snowfall from an orographic precipitation model employed in the western U.S. Snow density is a contributory factor in avalanche occurrence and a consideration in snow management programs, runoff predictions, high speed snow removal, and snow safety.

Snow density varies with crystal size, shape, and the degree of riming. Crystals may be hexagonal or spicular, clear or opaque, partly obscured by rime, or so rimed up the original forms are unrecognizable. Crystal size varies constantly. Smaller crystals are generally associated with colder temperatures and larger ones with warmer conditions, but a large range of sizes occurs at all temperatures. In particular, tiny crystals occur with both warm and cold conditions. Small particle sizes sometimes contribute to higher densities because they pack better. Crystals that fall through clouds with high concentrations of supercooled water become rimed and produce high density layers. LaChapelle, 1969, found a $15 \mathrm{~cm}$ deposit of heavily rimed needles a few hours old that had a density of $320 \mathrm{~kg} \mathrm{~m}^{-3}$; this value is greater than the density of metamorphosed contintental snowpacks months old. The event turned out to be more than academic because the occurrence caused widespread avalanching.

Density at the time of observation is a product of the initial density and any further densification due to prevailing weather conditions, overburden pressure, and the amount of time between deposition and measurement. Densities increase with pressure and time. The process is temperature-driven with the greatest density increases occurring at snow temperatures near $0^{\circ} \mathrm{C}$, and the least with temperatures near $-40^{\circ} \mathrm{C}$. The process associated with crystal alterations in the 
snowpack is called metamorphism. The original forms are slowly destroyed and gradually metamorphose into more rounded shapes. These modifications result in decreasing snow depth with time as the amount of pore space decreases while density increases. This basic feature of snow is ever present, and it is the reason that short measurement intervals give larger new snowfall totals than longer measurement intervals do for the same event. The physics of the process dictates rapid settlement initially followed by slowing rates of change as density rises. The higher the density, the greater the resistance to further densification.

A simple "rule of thumb" has developed through history to quantify and describe the density of fresh snow. The "ten-to-one rule" used to convert snowdepth from its water content likely originated from 19th Century snow density data from Toronto, Canada (Potter 1965). Anyone who has spent time observing snowfall knows from experience that snow density varies greatly from one snow event to the next and even from time to time within a single storm. Yet the "ten-to-one rule" persists and is still used to determine snowfall from water content and vice versa at some weather stations. Abbe (1888) warned 19th Century weather observers concerning the large errors associated with such a simplification, but more than 100 years later the practice continues.

From studies that have been published, the density of freshly fallen snow in the U.S. varies from $10 \mathrm{~kg} \mathrm{~m}^{-3}$ to about $350 \mathrm{~kg} \mathrm{~m}^{-3}$ (Diamond and Lowry, 1954; Wilson, 1955; LaChapelle, 1962; Judson, 1965; Grant and Rhea, 1974; McGurk et al. 1988; Doesken and Judson, 1997). Other pertinent contributions to the literature came from: Oda and Kudo 1941; Bossolasco 1954; Power et al. 1964; Gunn 1965; Stashko 1976; and Meister et al 1986. Most of these publications are not in mainstream meteorological literature, and the results have not been widely distributed among meteorologists. For this reason, and because of the general dependence of operational meteorologists on gauge data, snow density has not been available to most operational forecasters.

Gauge precipitation data are not used and cannot be used in place of water-equivalent because of undercatch problems (Goodison 1978). The difference between actual precipitation 
and catch from an unshielded gauge may exceed 50 percent for wind speeds of $3 \mathrm{~m} / \mathrm{s}$ at gauge top. Gauge precipitation therefore differs from snow water equivalent by the amount of undercatch. This disparity varies from site to site and is a function of site exposure and protection from wind. Figure 1 shows an example of gauge catch as a function of core precipitation in a wind protected forest opening. More exposed sites suffer much greater disparities.

Are density variations important? Suppose that $10: 1$ is used to estimate expected snowfall when the actual ratio is $40: 1$ in one instance or 3:1 in another? It takes more energy to shovel high density snow than low. A vehicle which rolls easily through fluff founders in higher density snow with more rolling resistance. Roof structures fail with fewer centimeters of high density snow than with lower density deposits. The likelihood of drifting snow and the amount of snow transported with a given windspeed is greater with 40:1 fluff than it is with 3:1 damp layers.

This work started in 1994. It began not from the pressing need to solve existing problems, but rather from pure curiosity. The senior author, once a Forest Service snow ranger, wondered how snow in the Steamboat Springs, $\mathrm{CO}$ area differed from snow in other mountain regions where he had worked all his life. It seemed that Steamboat and the Park Range immediately above it to the east, experienced a higher incidence of deep, low density snowfalls than occurred in other mountains. And unlike the Colorado Front Range snow climate, the Park Range had a higher frequency of denser snows. Also it experienced "upside down storms" or "inverted profiles" as snow rangers called them that rarely occurred in the Front Range. Such storms began with low density layers and ended with higher density layers which produced unstable snow in avalanche areas. The Park Range also had the deepest snowpack in the state winter after winter. The writer was filled with questions about these deep snows that could only be answered with data. The deepest snows occurred at a snow course named Tower which is situated near Buffalo Pass on the Continental Divide east of town. But Tower was remote and only accessible by oversnow vehicle. For that reason the senior author began measuring snow at Dry Lake, some 9 $\mathrm{km}$ further west, but at the end of the plowed road. After four years of sampling new snow every snowfall day at both Dry Lake and at his residence in Steamboat Springs, the new information 
was available. The data are presented here for dissemination to the greater snow community. Daily data from the two Steamboat Springs sites and high quality but previously unpublished data from avalanche stations located in the high mountains of Colorado and Wyoming are compared in this paper. Frequencies of individual new snow densities, the relationship between air temperature and density, and density variations between measurement sites are considered.

\section{Data}

With the exception of data collected by the first author in Steamboat Springs and at nearby Dry Lake, all data used in this study were from avalanche stations. Some were maintained by the U.S. Forest Service Alpine Snow and Avalanche Research Project, now defunct. One station was operated by the Wyoming Department of Highways and is now closed. Two stations were administered by the University of Colorado; both have since closed. Others, still active, belong to the Colorado Avalanche Information Center. All observers were skilled avalanche forecasters trained in special snow measurements. The locations of all measurement sites are shown in Figure 2 and described in Table 1.

The Steamboat Springs and Dry Lake data set represent hundreds of hours of volunteer data collection by the first author of this paper. The Steamboat Springs observations were taken at the observer's residence. Dry Lake is northeast of Steamboat Springs in the Park Range mountains. Measurements at this site required a $13 \mathrm{~km}$ drive on snow-covered roads followed by a one $\mathrm{km}$ cross country ski (Fig. 3). During January 1996, $480 \mathrm{~cm}$ of new snow was recorded there. On more than one occasion, snow flowed over the hood of the observer's vehicle enroute to collect the daily data. On the snowiest days it took at least one hour to make the round trip on skiis from the vehicle to the snow board and back, often in early morning darkness.

Observations at all sites consisted of once daily, early in the morning measurements of new snow depth and water content. New snow depth was measured on white snow boards set flush with the snow surface. All water-equivalent data were from cores extracted from the boards. At Wolf Creek Pass, a steel tube was used and samples were weighed. The remainder were cored 
using galvanized, $20 \mathrm{~cm}$ diameter cans. Cores were subsequently weighed or melted. Water from melted cores was poured into standard National Weather Service reduction tubes and measured. Sample age ranged from about one hour to just under 24 hours. All data were restricted to the November 1 through April 30 period to minimize radiation effects. The sites were located in wind-protected forest openings. The predominant stand types were spruce-fir, sometimes mixed with lodgepole pine and aspen. All samples involved new snow at least $2.5 \mathrm{~cm}$ in depth and free from wind effects, sleet, freezing rain, rain, freezing drizzle, drizzle, melt crusts or other snow with visible melting effects.

Densities measured at Dry Lake, Steamboat Springs, and Wolf Creek Pass are from the matching winters 1994-1995 through 1997-1998. The other four year sets used in the distributions are from the 1970s, with at least three matching winters each. Data used for interstation density plots are from the best data-observer combinations available.

\section{Frequency distributions}

Figure 4 histograms show the distributions of new snow densities for each observing site in the study for their full period of record. Densities ranged from $10 \mathrm{~kg} \mathrm{~m}^{-3}$ to $257 \mathrm{~kg} \mathrm{~m}^{-3}$ with individual station peak frequencies varying from 60 to $100 \mathrm{~kg} \mathrm{~m}^{-3}$. Measures of central tendency and other statistical details of the distributions are shown in Table 2. The lowest elevation site, located in the city of Steamboat Springs, CO, had the lowest average density of 72 $\mathrm{kg} \mathrm{m}^{-3}$, a peak frequency (mode) of $70 \mathrm{~kg} \mathrm{~m}^{-3}$, and a range from 15 to $168 \mathrm{~kg} \mathrm{~m}^{-3}$. This upper limit is a regional density characteristic of the northern Colorado snow climate.

Dry Lake had an average density of $77 \mathrm{~kg} \mathrm{~m}^{-3}$. The range varied from a sample low 10 $\mathrm{kg} \mathrm{m}^{-3}$ to a maximum of $160 \mathrm{~kg} \mathrm{~m}^{-3}$ with the peak at $90 \mathrm{~kg} \mathrm{~m}^{-3}$.

The Steamboat Springs area climate features a deep and persistent temperature inversion throughout the winter months. The phenomenon often results in snow deposition with little or no surface wind. As a result, total snow depths tend to be similar over fairly large areas although the usual variations in new snow amounts found elsewhere occur here as well. Steamboat Springs 
also has the lowest snowfall frequency, and generally shallower snowfalls than higher elevation sites used in this work. It shares with nearby Dry Lake a tendency for occasional very low density snowfalls of considerable depth. A daily fall of $36 \mathrm{~cm}$ of $23 \mathrm{~kg} \mathrm{~m}^{-3}$ snow was measured on January 19, 1996. The Dry Lake observation that day showed $45 \mathrm{~cm}$ of new snow with a density of $30 \mathrm{~kg} \mathrm{~m}^{-3}$. Small diameter, unrimed stellar crystals and small, clear plates were observed during both low density depositions.

Snowfalls with densities below $40 \mathrm{~kg} \mathrm{~m}^{-3}$ are called wild snow. Several snowfalls of this type occur annually in the Park Range. Both Steamboat Springs and Dry Lake have reported at least $8 \%$ of their daily snowfall with these very low densities. These events appear to be somewhat unique to the region, although lake-effect snows near the Great Lakes sometimes show similar densities (Eichenlaub 1979). These snow layers exhibit extremely low internal cohesion and present minimal resistance to travel. In terms of avalanches, this type of snow sometimes flows silently down steep slopes unrestrained by stands of timber and becomes airborne after reaching a relatively low threshold speed.

Teton Pass, WY, was the northernmost site in our sample. New snow densities there averaged $82 \mathrm{~kg} \mathrm{~m}^{-3}$ during the four winters ending in April 1974. The maximum daily value was $192 \mathrm{~kg} \mathrm{~m}^{-3}$, with the peak frequency at $70 \mathrm{~kg} \mathrm{~m}^{-3}$. This pass rises abruptly above the plains of Idaho and although the elevational change there is similar to that encountered further south in Utah's Wasatch Front, densities are closer to those measured in Colorado.

The Eisenhower Tunnel West Portal site lies adjacent to Interstate 70 directly west of Denver. Here, densities average $76 \mathrm{~kg} \mathrm{~m}^{-3}$, peak at $80 \mathrm{~kg} \mathrm{~m}^{-3}$, and range from 30 to $133 \mathrm{~kg}$ $\mathrm{m}^{-3}$, the narrowest of our data. The shape of the distribution is similar to that at nearby Berthoud Pass (Judson 1965). On the summit of Red Mountain Pass in Colorado's San Juan Massif, densities average $75 \mathrm{~kg} \mathrm{~m}^{-3}$, peak at $60 \mathrm{~kg} \mathrm{~m}^{-3}$, and range from 20 to $167 \mathrm{~kg} \mathrm{~m}^{-3}$. Despite its more southerly latitude, the general range and limits of densities at Red Mountain are similar to data from Steamboat Springs, Dry Lake and Teton Pass. 
Wolf Creek Pass, CO is located southeast of Red Mountain Pass by approximately 100 $\mathrm{km}$. The outstanding feature of new snow densities at Wolf Creek Pass is the shift to higher values throughout the distribution. No location in Colorado or Wyoming has reported higher densities in the literature, and the average of $103 \mathrm{~kg} \mathrm{~m}^{-3}$ is the highest reported in the Rocky Mountains. The minimum density there was $20 \mathrm{~kg} \mathrm{~m}^{-3}$ and the relatively long tail extended to $257 \mathrm{~kg} \mathrm{~m}^{-3}$. The extended peak frequency at $100 \mathrm{~kg} \mathrm{~m}^{-3}$ may be an artifact of rounding. There would be no physical reason for such a prominent peak with sharp declines on either side. To test this assumption, a separate distribution for this station based on $10 \mathrm{~cm}$ and greater snowfalls was made. That distribution shows a steady buildup to the $100 \mathrm{~kg} \mathrm{~m}^{-3}$ peak followed by a slow but steady frequency decline into the higher densities.

Large storms occur at Wolf Creek Pass with densities above $100 \mathrm{~kg} \mathrm{~m}^{-3}$, making this a snow climate of its own. Such storms repeatedly occur with southwest flow aloft bringing moisture from the Gulf of California and the subtropical Pacific. Heavily rimed crystals and graupel (snow pellets) are typical at Wolf Creek. Only one major barrier with elevations above $2000 \mathrm{~m}$ MSL stands between the pass and its southern moisture sources. This together with orographic blocking of northerly and northwesterly flow by upstream mountains is probably the reason for such sustained high densities. Rhea (1972) reported that the Wolf Creek area averages eight times more precipitation with $700 \mathrm{mb}$ southwest flow than it receives with north-northwest wind at that pressure level. These orographic influences combine to make Wolf Creek Pass snows atypical of most of the Colorado and Wyoming mountains.

Doesken and Judson (1997) previously presented density distributions from a few sites outside of Colorado and Wyoming: Alta, Utah; North Danville, Vermont; Girdwood, Alaska; Squaw Valley, California; and Stevens Pass, Washington. While most of these sites are systematically lower in elevation than the Colorado-Wyoming sites, and while air masses and synoptic conditions differ greatly, the general characteristics of snow density distributions are remarkably similar. The median density was 0.08 for these sites. Occasional low-density snows ( 0.04 or less) were evident at all sites. The main difference was that West Coast sites included a 
higher frequency of very dense snowfalls. The North Danville, Vermont, data showed a distribution very similar to the central Rocky Mountains.

\section{Relation of density to temperature}

Crystal type and degree of riming are temperature dependent. Since these factors are partial determinants of the density of fresh snow, the relationship between density and temperature has been studied for climatological applications and in hopes of finding a means of predicting density in advance of snowfalls. Results of previous work show two recurring patterns: (1) a non-linear decrease in snow density with decreasing temperature (LaChapelle 1962, McGurk 1988) or (2) a parabolic relationship with density increasing at both warm and cold ends of the curve with a density minimum in between (Grant and Rhea, 1974). The density minimum, when adjusted for temperatures near the ground, coincides with the dendritic growth range of snow crystals. Dendrites have been assumed to give the lowest densities, but recent observations at both Steamboat Springs and Dry Lake show that while unrimed stellar crystals are observed in very low density snowfall, unrimed plates and small diameter assemblages of plates mix with stellars in such snows. Fresh snow density-temperature correlations to date have been weak, show considerable scatter, and have $r$ values below about 0.6 , so predictive potential has been limited.

We tested four winters of new snow density at Dry Lake, $\mathrm{CO}$, with air temperature at nearby Storm Peak Laboratory (SPL) (Borys 1997). SPL is $9.5 \mathrm{~km}$ southeast of and $640 \mathrm{~m}$ higher than Dry Lake. It is frequently immersed in heavy clouds during the synchronous snowfalls that occur at the two sites. SPL is slightly above the average $700 \mathrm{mb}$ level. Free air sounding temperatures were not used in this density study because of their limited availability (twice daily) and because of uncertainties that arise from interpolating between distant upper air stations. Grand Junction, CO, Salt Lake City, UT, Lander, WY (recently moved to Riverton), and Denver, $\mathrm{CO}$, are pertinent stations, but the closest one, Denver, is $200 \mathrm{~km}$ distant and east of the mountain barrier. Since temperatures usually change with time during snow events, temperatures at SPL 
were chosen to coincide with the centroid of each day's most intense snowfall in order to most closely match air temperature with the new snow stratums' density. A recording precipitation gauge trace, $50 \mathrm{~m}$ from the snow board was used for timing. By using in-cloud temperature data from a nearby site, it was hoped that scatter associated with using ground-based temperatures or interpolating upper-air temperatures could be reduced.

The resulting scattergram in Figure 5 shows new snow densities decline with temperature over the range $0^{\circ} \mathrm{C}$ to $-20^{\circ} \mathrm{C}$ but with considerable scatter. The correlation is weak with $\mathrm{r}=0.52$ results are similar to those achieved by Diamond and Lowry (1954), LaChapelle (1962), McGurk et al. (1988) and Super and Holroyd (1997). While there is a hint of a second population below $-15^{\circ} \mathrm{C}$ where density appears to increase somewhat with lower temperature, the main core of data continues to decline with temperature through $-20^{\circ} \mathrm{C}$.

There is some evidence here to suggest that there are situations where densities of $100 \mathrm{~kg}$ $\mathrm{m}^{-3}$ or higher occur at cold temperatures $\left(-15^{\circ} \mathrm{C}\right.$ and colder) as suggested by Grant and Rhea (1974). However, a reversal to higher densities at colder temperatures, if it occurs, is not the dominant mode at the Dry Lake observing site. Neither is there evidence to support a continued linear decrease in density with decreasing temperatures as is currently shown in the National Weather Service Handbook No. 7 (U.S. Department of Commerce 1994). Our analysis of this phenomenon suffered from a lack of an adequate sample of snowfall events at very cold temperatures. The old adage, "It's too cold to snow" does have at least partial truth to it, as the number of snowfall events dropped off rapidly below about $-18^{\circ} \mathrm{C}$.

The large variability in densities at warmer temperatures is also of interest. Dry Lake density variations associated with cloud temperatures of 0 to $-5^{\circ} \mathrm{C}$ (as represented by the SPL readings) have ranged from $160 \mathrm{~kg} \mathrm{~m}^{-3}$ down to nearly $60 \mathrm{~kg} \mathrm{~m}^{-3}$. While warm temperature snows may have mean densities near $100 \mathrm{~kg} \mathrm{~m}^{-3}$ (snow to water ratio of ten to one), that value is an average of a widely dispersed population. The density versus temperature question will not be resolved easily, and there is still plenty of room for future observations, analysis and discussion. 


\section{Effect of new snow depth on density}

It has been long surmised that the deepest daily snowfalls have higher densities than shallower ones with the reason being the increased weight of the layer acting to densify itself. To test this assumption we selected snowfalls from five measuring sites with similar density regimes. A group with 70 daily snowfalls exceeding $30 \mathrm{~cm}$ was compared with a group of 381 snowfalls less than $15 \mathrm{~cm}$ in depth. Average density of the first group was $75 \mathrm{~kg} \mathrm{~m}^{-3}$ while the latter group averaged $74 \mathrm{~kg} \mathrm{~m}^{-3}$.

The results are similar to work by LaChapelle (1962) and Meister et al. (1986) who showed no clear relationship between snow depth and density. In fact, some of the deepest snowfalls have low densities. A daily snowfall of $71 \mathrm{~cm}$ with a density of $50 \mathrm{~kg} \mathrm{~m}^{-3}$ occurred at Stevens Pass, WA. From our samples, a $60 \mathrm{~cm}$ daily snowfall at Red Mountain Pass had a density of $60 \mathrm{~kg} \mathrm{~m}^{-3}$, and there was the Dry Lake case of $45 \mathrm{~cm}$ of new snow with density $30 \mathrm{~kg} \mathrm{~m}^{-3}$. The higher density regime at Wolf Creek Pass included a $60 \mathrm{~cm}$ snowfall with a density of $70 \mathrm{~kg}$ $\mathrm{m}^{-3}$, well below the average for that site.

\section{Spatial variation of new snow density}

Work by LaChapelle (1958, 1962, 1969); McGurk et al (1988); and Super and Holroyd (1997) shows that new snow density varies with snow climate. As shown in Fig. 4, densities at Wolf Creek Pass, $\mathrm{CO}$ are decidedly higher than those in the rest of the Colorado mountains. It follows that new snow densities vary with distance between measurement sites. McGurk et al (1988) with identical technique and equipment as used in this study found average density differences between samples from adjacent boards in a forest clearing to be 0.13 percent. Our data, tested separately, show an average difference of 0.5 percent in samples taken from snow boards one meter apart. Since measurement technique does not appear to contribute to new snow density variations, the disparities must be attributable to other factors.

The smallest separation between measurement sites in our work was the $7.2 \mathrm{~km}$ distance between Dry Lake and Steamboat Springs. The average new snow density difference between 
these sheltered sites was 11 percent. During the first winter of observations at Dry Lake, 62 percent of the densities paired with those measured at Steamboat Springs were within $\pm 10 \mathrm{~kg}$ $\mathrm{m}^{-3}$. The maximum disparity was $37 \mathrm{~kg} \mathrm{~m}^{-3}$.

Figure 6 shows $r$ values decreasing with increasing separation between measurement sites in Colorado. The value $r=0.99$ was derived from snowboards one meter apart in Steamboat Springs. Beyond $10 \mathrm{~km}$, correlation coefficients were uniformly below 0.7 and reached 0.34 at 335 km (Dry Lake/Wolf Creek).

A sample of interstation snow density scattergrams is shown in Fig. 7. No outliers were removed. A band of scatter some $60 \mathrm{~kg} \mathrm{~m}^{-3}$ wide was common to all plots. The high value outlier in Fig. 7d came from a localized fall of nearly 100\% graupel at Gothic. Graupel from that storm produced a spot density of $169 \mathrm{~kg} \mathrm{~m}^{-3}$, the highest new snow density reading recorded in more than two decades of record in the Gothic-Crested Butte area. Gothic's daily new snow densities are poorly correlated $(r=0.36)$ with those at Dry Lake $265 \mathrm{~km}$ further north. The apparent ceiling on Gothic densities near $80 \mathrm{~kg} \mathrm{~m}^{-3}$ in Fig. 7e is an artifact resulting from nonsynchronous snowfalls at Gothic and Dry Lake. Higher densities at Gothic were recorded that winter, but those occurred when Dry Lake was terrain shadowed from southwest flow aloft, so corresponding snowfall was absent at the more northerly site. If the reader will place an imaginary 10:1 data point in each of these scattergrams, the case for not using 10:1 in Colorado is clear.

Scatter in interstation relationships derives from several sources. Some known primary causes for variation are site location and the ever important exposure and protection from wind. Since our sites are all well protected, this discussion centers on variations related to accuracy of measurement, timing, and orography.

\section{a. Accuracy of measurement}

Snowfall at some avalanche stations used in this work was measured to the nearest 1.3 $\mathrm{cm}$. Dry Lake and Steamboat Springs snow depth measurements were made to the nearest 0.2 
$\mathrm{cm}$. The seemingly small difference in precision is inconsequential given deep snowfalls, but adds scatter when new snow depths are below about $10 \mathrm{~cm}$. Rounding a new snow depth to $4 \mathrm{~cm}$ when it actually is $3.6 \mathrm{~cm}$ with $2 \mathrm{~mm}$ water equivalent, yields a density difference of more than $10 \%$. Use of the old National Weather Service direct conversion weighing scales (for 8-inch gauge precipitation) gives $\pm 2.5 \mathrm{~mm}$ accuracy on water-equivalent due to stick-slip in its mechanism. Largest error percentage from this source occurs with shallow, low density snows. Additional error derives from minor reflective differences on snow boards which have been observed to cause depth differences up to 30 percent during warm conditions. Even the material beneath a snow board affects new snow depth on a board when temperatures are near $0^{\circ} \mathrm{C}$. $\mathrm{A}$ snow board on warm bare ground at Steamboat Springs has been observed to have snow depths of about one $\mathrm{cm}$ below those on an adjacent board resting on snow.

\section{b. Timing}

Density samples should be time matched, but due to various constraints, simultaneous sampling is seldom achieved. The time of observation at Dry Lake was usually an hour earlier than the Steamboat Springs reading because of travel time. The problem appears when heavy snowfall occurs at observation time. Density from the site read earliest can be quite different from that of the stratum deposited in between observation times as new snow density may change with time. Obviously, the shallower the layer affected and the more intense the between reading precipitation, the greater the potential difference in the two observations. Scatter in the density relationships between Steamboat Springs and Dry Lake is thus greater than would occur with simultaneous sampling.

As the distance between measurement sites increases, the time distribution of snowfall at those sites changes. This affects settlement rates and ultimately density at observation. If snowfall is concentrated solely in the first part of the measurement period at one station, and solely in the last part of said period at the second station, density differences caused by differing settlement rates can amount to 8 percent, according to Meister's (1986) calculations. A 15 
percent density difference due to settlement can occur with identical water-equivalents when the snowfall distribution is evenly distributed throughout the measurement period at one station but occurs only during the last part of the period at the second site. These disparities are due solely to changes in strain rates acting on the material.

\section{c. Degree of riming}

The presence or absence of rime on snow crystals strongly affects density. Pure falls of well developed graupel produce initial densities in the range from about 120 to $250 \mathrm{~kg} \mathrm{~m}^{-3}$. Experience with data from western avalanche stations indicates that such episodes are small scale phenomena (such as occurred at Gothic, $\mathrm{CO}$ ) restricted to small sections of a mountain range. Rarely does more than one avalanche station report consequential layers of graupel on a given day. Whenever there are differences in riming between reporting sites, the densities will be dissimilar.

\section{d. Orography}

Mountain barriers modify airmass properties that create special snow climates. New snow density distributions within snow climates are somewhat unique to each mountain range. Highest U.S. new snow densities are found in the Olympic mountains of Washington where average daily

new snow densities of $250 \mathrm{~kg} \mathrm{~m}^{-3}$ have been recorded (LaChapelle 1958). Lower densities occur in the Cascades and Sierra with even lower densities in the Rocky Mountains. Needless to say, snow densities between stations in different snow climates produce low correlations and high scatter. Comparison of the density of daily snowfalls between Alta, UT, and Dry Lake produced $r$ values of 0.25 . Those between Dry Lake and Wolf Creek resulted in $r=0.34$. The fact that there is any correlation at all may be significant relating, perhaps, to the broader airmass characteristics of temperature and humidity. No data were available for comparing densities at nearby sites with orographically different exposures, but it appears likely that large differences in density could occur over short distances as a function of differing slopes and aspects. 


\section{Densification of dry new snow on the ground}

Most of our attention in this paper has been focused on freshly fallen snow. Densification over time of accumulated snowfall on the ground is also a quiet but interesting process. As snow ages prior to melting, many changes occur within the snowpack that lead to increased density. Density differences measured in the new snow layers tend to diminish as snow densifies with age. The process begins at deposition and may or may not be immediately noticeable as stellar branches and other extensions, when present, have enough strength to hold the initial structure in place for some hours. In the absence of strong temperature gradients, crystals and their broken remnants metamorphose from their high curvature - high energy state to lower energy spherical grains. The complex process causes reduction of surface area of the crystals and leads to diminished pore space as the high mobility grains are displaced into pore space to accommodate strain. The snow surface boundary subsides. With rapid settlement, inverted snow cones are left around small diameter trees and bushes as a temporary reminder of the processes taking place within.

Densification is temperature and load dependent with rate increasing with temperature and overburden pressure. The general form, following the initial densification which may be inhibited by structure and low temperature, is for rapid density increases in the first 10 days to two weeks followed by decreasing rate of densification with time (Judson et al 1980). For cold, light snowfall climates like Colorado's high elevation Front Range, densification in the first 100 days is approximated by:

$$
\text { Density }=0.11 *\left(\text { Days }^{* *} 0.18\right)
$$

For heavier snowfall climates exhibiting many $15 \mathrm{~cm}$ to $40 \mathrm{~cm}$ snowfall days and with warmer temperatures such as those in the Wasatch Front in Utah, early season densification is better approximated by:

$$
\text { Density }=0.18 *\left(\text { Days }^{* *} 0.19\right)
$$


When strong temperature gradients develop in the snowpack, a different type of metamorphism ensues and new crystals with stepped and angular facets are formed. The end process of this metamorphism produces depth hoar. Under such conditions the rate of densification slows markedly after reaching about $250 \mathrm{~kg} \mathrm{~m}^{-3}$ (Armstrong 1980). It is approximated by:

$$
\text { Density }=0.08 *(\text { Days**0.31) }
$$

These functions and others not shown were developed and tested in an experimental avalanche forecast model in Colorado (Judson et al 1980). The functions are given here to illustrate the early season densification process in cold dry snow. Warmer and heavier snow climates will show higher initial densities and higher rates of densification. In Figure 8 these functions and the densification curve for a very heavy snowfall area in the Olympic Mountains of Washington are given. The curves for the slow densification for the Front Range and the high rates at Mt. Olympus bracket the range of densification processes in the U.S. Extreme temperature gradient snowpacks in the arctic densify more slowly than Colorado snow.

This paper does not address snow melt which adds yet another dimension and variability to snow density. Combining all densification processes, densities within deep snowpacks commonly reach values of $300 \mathrm{~kg} \mathrm{~m}^{-3}$ to $500 \mathrm{~kg} \mathrm{~m}^{-3}$ before melting.

\section{Summary and conclusions}

Large variations in daily new snow densities have been observed at sites in the central Rocky Mountains in Colorado and Wyoming. Daily new snow densities from sheltered avalanche reporting sites ranged from 10 to $257 \mathrm{~kg} \mathrm{~m}^{-3}$ while peak frequencies were distributed from 60 through $100 \mathrm{~kg} \mathrm{~m}^{-3}$.

Steamboat Springs and Dry Lake, located on the west flanks of Colorado's Park Range, have occasional very low density snowfalls with depths exceeding $30 \mathrm{~cm}$. Part of the observed crystal mix in these wild snow episodes included small, unrimed stars and plates, and assemblages of tiny plates. While other high elevation reporting sites experience wild snow occasionally, accompanying depths are normally under $10 \mathrm{~cm}$. The deep fluff deposits in the Park Range are a 
special feature of the snow climate there and contribute to the region's reputation for powder snow. Wild snow episodes appear to originate in shallow cloud systems of limited extent; this makes them very difficult to forecast. Calm conditions at the surface accompany most Park Range snowfalls below about $2700 \mathrm{~m}$ on the west side of the Continental Divide.

An upper density limit of about $160 \mathrm{~kg} \mathrm{~m}^{-3}$ is common for Colorado mountain snowfalls outside the Wolf Creek Pass region. By comparison, at Wolf Creek Pass, cold snow densities to $257 \mathrm{~kg} \mathrm{~m}^{-3}$ have been recorded in the sheltered study plot. Daily, Wolf Creek Pass snowfalls averaged $103 \mathrm{~kg} \mathrm{~m}^{-3}$, the highest average of new snow density reported in the U.S. Rocky Mountains. Wolf Creek Pass appears to have a snow climate of its own, featuring high density snowfalls with southwest flow aloft. Moisture sources include the Gulf of California and lower latitudes of the North Pacific. Colder snows, which would occur with northwest through northerly flow at Wolf Creek, are blocked by upwind mountain ranges.

Cloud-level air temperature is a factor in explaining some of the observed variation in snow density. Density at Dry Lake was observed to be weakly related to temperatures at SPL with temperature variations explaining only about one-fourth of the observed variance. The general pattern is a decrease with temperature but with considerable scatter, similar to findings by LaChapelle at Alta, UT, and McGurk at the CSSL in the Sierras. It appears from other research that the temperature - density relationship in mountainous areas may be site specific with a parabolic relationship applying to some sites and the non-linear decrease with temperature applying to others.

New snow density is unrelated to the depth of the deposit, a conclusion in agreement with the results presented by Meister (1986).

Interstation density correlation decreases steadily with increasing distance between measurement sites. $R$ values for station separations beyond $10 \mathrm{~km}$ were uniformly below 0.7 . Daily density disparities on the order of $\pm 10 \mathrm{~kg} \mathrm{~m}^{-3}$ are common at sites less than $10 \mathrm{~km}$ apart, but values from adjacent snow boards have average differences below 1 percent, indicating that time honored techniques for obtaining cores from snow boards produce consistent results. 
Although shelter from wind is fundamental at any snow measurement site, accuracy of measurement, timing, orography, and degree of crystal riming - especially with graupel versus other types of crystals - are important factors determining the degree of disparity between new snow density readings at adjacent stations.

Densification of dry cold snow on the ground shows a pattern of rapid increase in the first 10 days to 2 weeks followed by a decline in the rate of densification. Major determinants of layer density include initial density of the layer, temperature, type of metamorphism and load. In general, snowpack density increases going west through the Rockies toward the coast due to higher initial densities, increasing temperature and deeper snowfalls (Armstrong and Armstrong, 1987).

Data used in this study were gathered by highly trained personnel. Accuracy of both net snow depth and its water-equivalent was high. Unfortunately, such data are not presently available from most U.S. weather stations because of poor site exposure, inconsistent snowfall measurement technique and heavy reliance on gauge data without supplement snow core information. This is a serious shortcoming in U.S. climate data, and one that deserves attention today. Because of the importance of snow density for many applications and the difficulty of inferring it from other standard observations, it is critical that more effort be made to collect accurate snow density data.

With a concerted but relatively small effort, existing weather stations could easily gather the necessary data; specifically, an accurate daily measurement of new snow accumulation from an appropriate and representative exposure at a consistent time of day at all stations and an accurate core measurement of the water content of that snow accumulation. With that type of data, snow density and its variations can be documented, and applications can be made. Up to this time, most density measurements have been taken by snow scientists and avalanche specialists. Now it is time for meteorologists and climatologists to join in. From an economic perspective, we need to improve our knowledge and appreciation of snow density variations at low elevations and in urban areas as well as in avalanche-prone mountain ranges of the West. This is very important for 
improved planning and management of snow removal activities for which several billion dollars are currently being spent annually (Minsk 1998), and for the monitoring of structural snow loads and the design of future structures. The recent automation of airport weather observations across the U.S. has ended most airport snowfall observations and degraded winter precipitation measurements. But with a little conviction and creativity, solutions can be found. For the benefit of the myriad of climate data users in this country, it is time to make snow density a part of the observation program. It is time to finally realize that "ten-to-one" is a possible snow to water ratio but not the only one.

\section{Acknowledgments}

This work was conducted with support from the U.S. Bureau of Reclamation, Contract \#1425-97-PG-81-65337 and the Colorado Agricultural Experiment Station.

\section{References}

Abbe, C., 1888: 1887 Annual Report of the Chief Signal Officer of the Army under the direction of Brigadier-General A. W. Greeley, Appendix 46. U.S. Gov. Printing Office, Washington, D.C., p. 385-386.

Armstrong, R. L., 1980: An analysis of compressive strain in adjacent temperature-gradient and equi-temperature layers in a natural snow cover. J. Glaciol., 26(94), 283-289.

Armstrong, R. L., and B. R. Armstrong, 1987: Snow and avalanche climates of the western United States: a comparison of maritime, intermountain and continental locations. IAHS Publ., 162, 281-294.

Borys, R. D., 1997: Storm peak laboratory: A research, teaching, and service facility for the Atmospheric Sciences. Bull. Amer. Meteor. Soc., 78, 2115-2123. 
Bossolasco, M., 1954: Newly fallen snow and air temperature. Nature, 174, 362-363.

Diamond, M. and W. P. Lowry, 1954: Correlation of density of new snow with 700-millibar temperature. J. Meteor., 11, 512-513.

Doesken, N. J. and A. Judson, 1997: The snow booklet: A guide to the science, climatology, and measurement of snow in the United States. Colorado State University, Fort Collins, CO 80523-1371, ISBN: \#0-9651056-2-8 (2nd Edition), 87 pp.

Eichenlaub, V., 1979: Weather and Climate of the Great Lakes Region. University of Notre Dame Press, Notre Dame, IN, p 160-163.

Goodison, B.E., 1978: Accuracy of Canadian snow gauge measurements. J. Appl. Meteorol., 27, $1542-1548$.

Grant, L. O. and J. O. Rhea, 1974: Elevation and meteorological controls on the density of snow. Adv. Concepts Tech. Study Snow Ice Resourc. Interdiscip. Symposium, National Academy of Science, Washington, DC, p. 169-181.

Gunn, K.L.S., 1965: Measurements on new-fallen snow. McGill University Stormy Weather Group Scientific Report MW-44. Prepared for U.S. Air Force, Contract No. AF19(628)249, Bedford, Mass, 27 pp.

Judson, A., 1965: The weather and climate of a high mountain pass in the Colorado Rockies. Research Paper RM-16, USDA Forest Service, Fort Collins, CO, 1-28.

Judson, A., C. F. Leaf, and G. E. Brink, 1980: A process-oriented model for simulating avalanche danger. J. Glacial., 26(94), 53- 63.

LaChapelle, E. R., 1958: Winter snow observation on Mt. Olympus. Proc. 26 Annual Meeting Western Snow Conf., 59-63. 
LaChapelle, E. R., 1962: The density distribution of new snow. USDA Forest Service, Wasatch National Forest, Alta Avalanche Study Center, Project F, Progress Report No. 2, Salt Lake City, UT, 1-13.

LaChapelle, E. R., 1969: Field guide to snow crystals. University of Washington Press, 101 pp. McGurk, B., D. Azuma, and R. Kattelmann, 1988: Density of new snow in the central Sierra Nevada. Proc. 56 Annu. Meeting Western Snow Conf., 158-161.

Meister, R., 1986: Density of new snow and its dependence on air temperature and wind. Proc. Workshop on the correction of precipitation measurements. B. Sevruk, editor. Eidgenossische Technische Hochschule Zurich, Switzerland. 73-80.

Minsk, L.D., 1998: Snow and Ice Control Manual for Transportation Facilities. McGraw-Hill, New York, NY, 11-12.

Oda, T., and K. Kudo, 1941: Properties of snow and its density. Seppyō 3. 109-121. SIPRE Translation No. 14. Corps. Eng., U.S. Army, Wilmette, III. 21 pp. [Available from Librarian, USACRREL, 72 Lyme Rd. Hanover, NH 03755-1290]

Potter, J.G., 1965: Water content of freshly fallen snow. CIR-4232, TEC-569, Meteorol. Branch, Dept. of Transport, Toronto, Ont., Canada.

Power, B. A., P. W. Summers and J. D'Avignon, 1964: Snow crystal forms and riming effects as related to snowfall density and general storm conditions. J. Meteor., 21, 300-305.

Rhea, J.O., 1972: Interpreting orographic snowfall patterns. M.S. Thesis. Atmospheric Science Department, Colorado State University, Fort Collins, CO 80523-1371, 135 p. (Available from Morgan Library, Call \# QC929.S7 R48)

Stashko, E. V., 1976: Water in freshly-fallen snow. Proc. 44 Annu. Meeting Western Snow Conf., 20-22. 
Super, A. B. and E. W. Holroyd, III, 1997: Snow accumulation algorithm for the WSR-88D radar: Second annual report. U.S. Dept. of Interior, Bureau Reclamation Technical Rpt. R-97-05. Denver, CO, $77 \mathrm{pp}$.

Wilson, W. T., 1955: The density of new-fallen snow. Weekly Weather and Crop Bulletin, 42(51), 7.

U.S. Department of Commerce, 1994: National Weather Service Handbook No. 7. NOAA, NWS, Office of Systems Operation, Washington, DC, p. B-21. 
Table 1.

Site information for snow density data collection sites in

Colorado and Wyoming used in this study.

\begin{tabular}{|c|c|c|c|c|c|}
\hline Station name & Lat & Long & Elev, $\mathrm{m}$ & Observer & $\begin{array}{l}\text { Period of } \\
\text { Record }\end{array}$ \\
\hline \multicolumn{6}{|c|}{ Primary Stations for Density Comparisons } \\
\hline Steamboat Springs & $40^{\circ} 28^{\prime}$ & $106^{\circ} 49^{\prime}$ & 2120 & Art Judson & $1994-98$ \\
\hline Dry Lake & $40^{\circ} 32^{\prime}$ & $106^{\circ} 47^{\prime}$ & 2560 & Art Judson & $1994-98$ \\
\hline Teton Pass & $43^{\circ} 30^{\prime}$ & $110^{\circ} 57^{\prime}$ & 2440 & Wyoming Dept. of Highways & $1970-74$ \\
\hline $\begin{array}{l}\text { Eisenhower Tunnel } \\
\text { West Portal }\end{array}$ & $39^{\circ} 41^{\prime}$ & $105^{\circ} 55^{\prime}$ & 3360 & $\begin{array}{l}\text { USFS Alpine Snow and Aval. } \\
\text { Research Project }\end{array}$ & $1976-80$ \\
\hline Red Mountain Pass & $37^{\circ} 54^{\prime}$ & $107^{\circ} 43^{\prime}$ & 3400 & $\begin{array}{l}\text { University of Colorado San } \\
\text { Juan Avalanche Project }\end{array}$ & $1972-76$ \\
\hline Wolf Creek Pass & $37^{\circ} 29^{\prime}$ & $106^{\circ} 47^{\prime}$ & 3244 & Colo. Aval. Info. Center & $1994-98$ \\
\hline \multicolumn{6}{|c|}{ Supplemental Data } \\
\hline Silverton & $37^{\circ} 49^{\prime}$ & $107^{\circ} 40^{\prime}$ & 2830 & $\begin{array}{l}\text { University of Colorado, San } \\
\text { Juan Avalanche Project }\end{array}$ & \\
\hline Gothic & $38^{\circ} 58^{\prime}$ & $106^{\circ} 59^{\prime}$ & 2896 & Bill Barr & \\
\hline Berthoud Pass & $39^{\circ} 48^{\prime}$ & $105^{\circ} 45^{\prime}$ & 3450 & $\begin{array}{l}\text { USFS Alpine Snow and Aval. } \\
\text { Research Project }\end{array}$ & \\
\hline $\begin{array}{l}\text { Storm Peak } \\
\text { Laboratory }\end{array}$ & $40^{\circ} 27^{\prime}$ & $106^{\circ} 44^{\prime}$ & 3210 & Desert Research Institute & $1994-98$ \\
\hline
\end{tabular}


Table 2.

Comparative snow density characteristics.

\begin{tabular}{|c|c|c|c|c|c|c|c|c|c|c|c|}
\hline \multirow[b]{2}{*}{ Station } & \multirow{2}{*}{$\begin{array}{l}\text { No. of } \\
\text { winters } \\
\text { sampled }\end{array}$} & \multirow{2}{*}{$\begin{array}{l}\text { Daily } \\
\text { snow } \\
\text { events } \\
>2.5 \mathrm{~cm}\end{array}$} & \multicolumn{7}{|c|}{ Density Characteristics $\left(\mathrm{kg} \mathrm{m}^{-3}\right)$} & \multicolumn{2}{|c|}{$\begin{array}{l}\text { Percent of events } \\
\text { with densities }\end{array}$} \\
\hline & & & Least & Greatest & Mean & Median & Mode 1 & $\begin{array}{l}\text { Standard } \\
\text { Deviation }\end{array}$ & $\begin{array}{l}\text { Weighted } \\
\text { Mean* }\end{array}$ & $\begin{array}{l}<40 \\
\mathrm{~kg} \mathrm{~m}^{-3}\end{array}$ & $\begin{array}{l}\geq 110 \\
\mathrm{~kg} \mathrm{~m}^{-3}\end{array}$ \\
\hline Steamboat Springs & 4 & 171 & 15 & 168 & 72 & 70 & 70 & 28 & 72 & 8.8 & 9.9 \\
\hline $\begin{array}{l}\text { Eisenhower Tunnel } \\
\text { West Portal }\end{array}$ & 4 & 307 & 30 & 133 & 76 & 75 & 80 & 18 & 76 & 0.3 & 6.2 \\
\hline Red Mountain Pass & 4 & 271 & 20 & 167 & 75 & 72 & 60 & 26 & 77 & 3.3 & 13.0 \\
\hline
\end{tabular}

1 Mode in intervals of 10.

* weighted by depth of fresh snow for each event. 


\section{List of Figure Captions}

Figure 1. Daily precipitation measurements from an unshielded $20.3 \mathrm{~cm}$ (eight-inch) diameter precipitation gauge as a function of water-equivalent from snow board cores at Berthoud Pass, CO, during the winter of 1971-1972. The measurement site is an ideal exposure in a naturally sheltered clearing surrounded by a mature spruce-fir forest at an elevation of $3450 \mathrm{~m}$ MSL.

Figure 2. Location of Colorado and Wyoming snow density measuring sites used in this study (open triangles). Cloud-level temperature data were obtained from the Storm Peak Laboratory (SPL - small circle). Supplemental comparative density data (small plus signs) were utilized from Berthoud Pass (BP), Gothic (GOT), Silverton (SIL), and Winter Park (WP) avalanche research sites.

Figure 3. Arthur Judson enroute to the Dry Lake snow density measuring site.

Figure 4. New snow density distributions from the Colorado and Wyoming measurement sites.

Figure 5. Daily new snow densities at Dry Lake, $\mathrm{CO}$ as a function of temperature at Storm Peak Laboratory, winters 1994-95 through 1997-98.

Figure 6. Correlation coefficient $\mathrm{r}$ for synchronous daily observed snow densities as a function of distance between density measurement sites.

Figure 7. Interstation snow density scattergrams.

Figure 8. Mean layer density for existing cold snowpacks as a function of age in the first 100 days. 


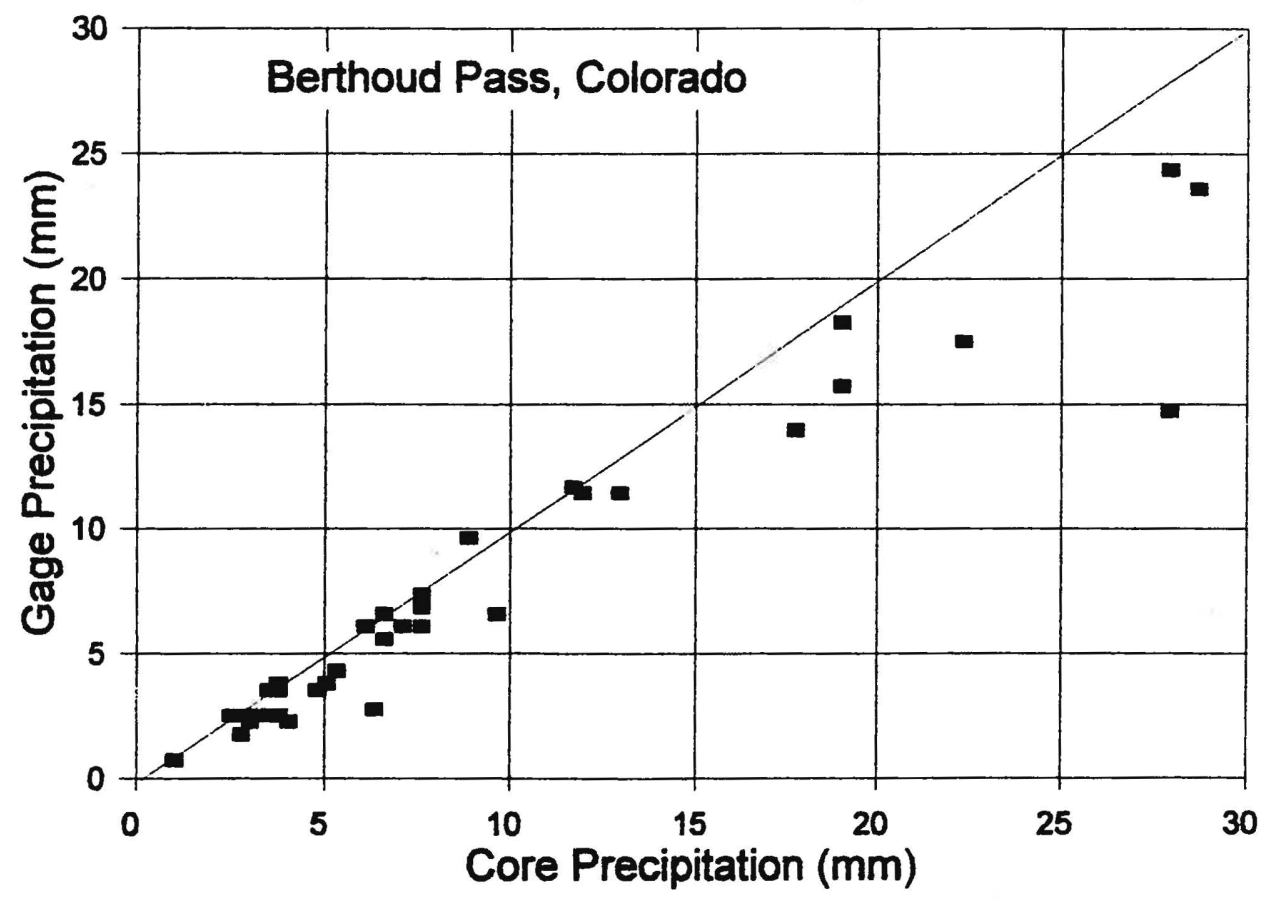

Figure 1. Daily precipitation measurements from an unshielded $20.3 \mathrm{~cm}$ (eight-inch) diameter precipitation gage as a function of water-equivalent from snow board cores at Berthoud Pass, CO, during the winter of 1971-1972. The measurement site is an ideal exposure in a naturally sheltered clearing surrounded by a mature spruce-fir forest at an elevation of $3450 \mathrm{~m}$ MSL. 


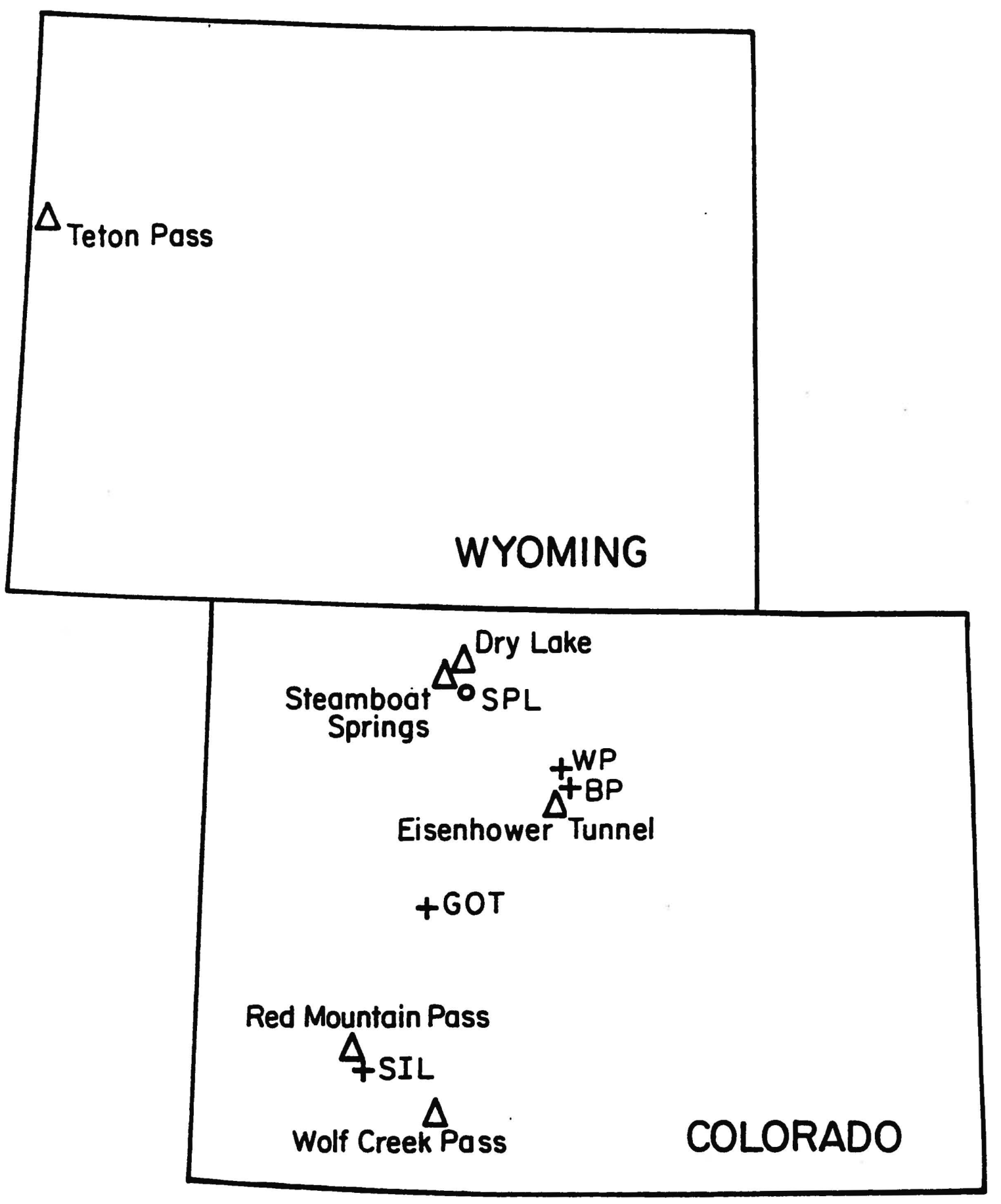

Figure 2. Location of Colorado and Wyoming snow density measuring sites used in this study. Cloud-level temperature data were obtained from the Storm Peak Laboratory (SPL -- small triangle). Supplemental comparative density data were utilized from Berthoud Pass (BP), Gothic (GOT), and Silverton (SIL) avalanche research sites. 

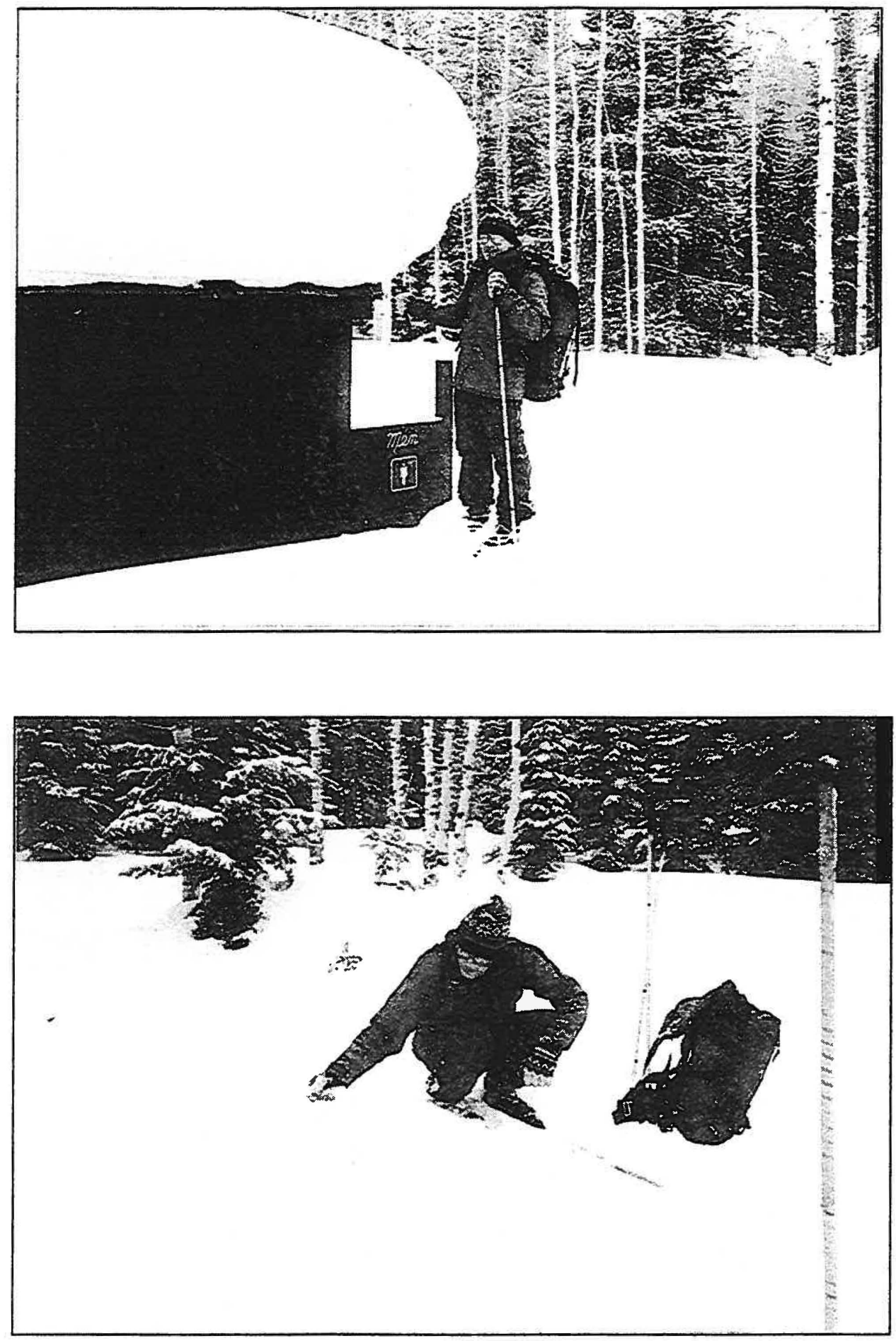

Figure 3. Arthur Judson enroute to the Dry Lake snow density measuring site. 

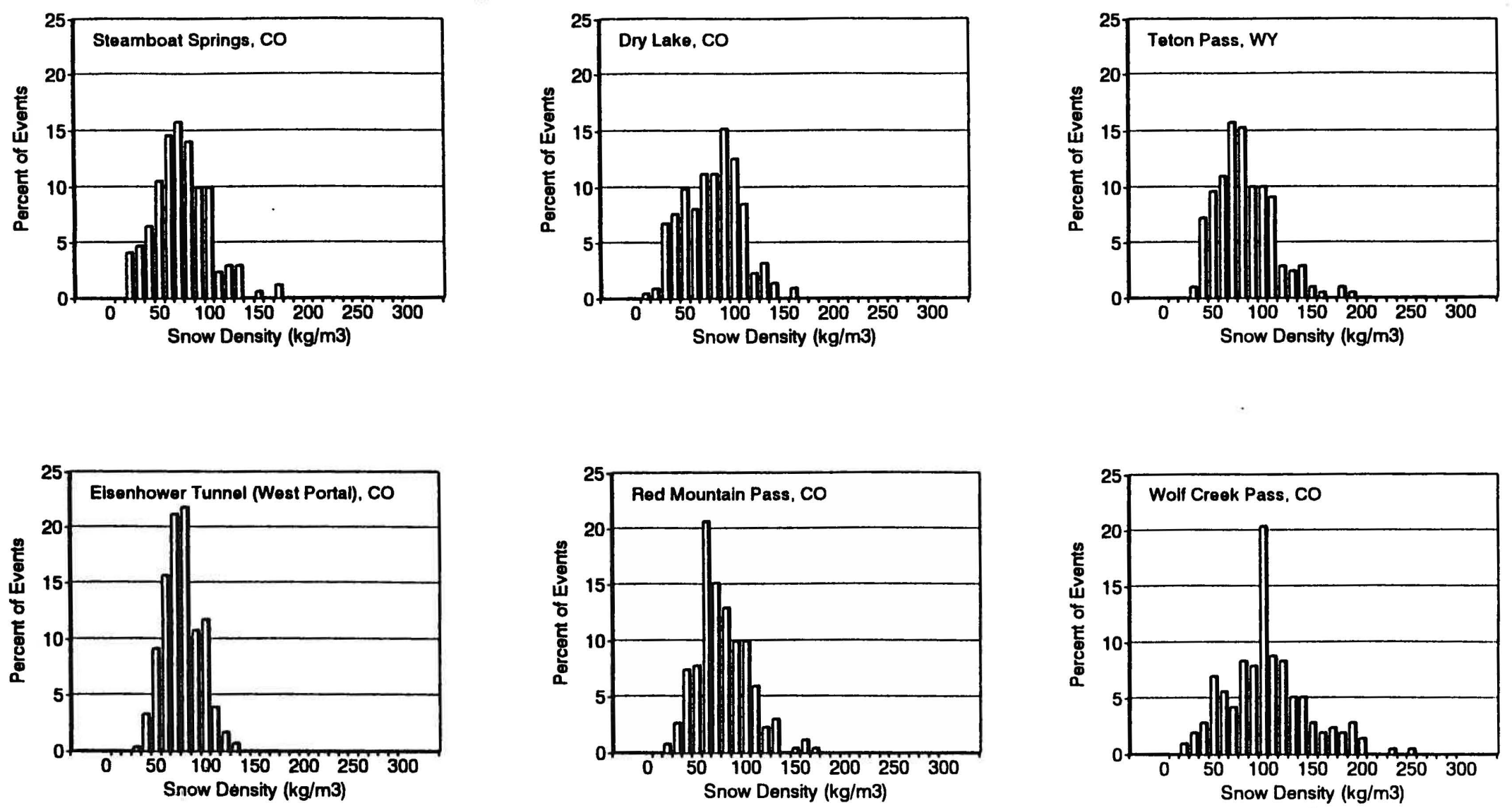

Figure 4. New snow density distributions from the Colorado and Wyoming measurement sites. 


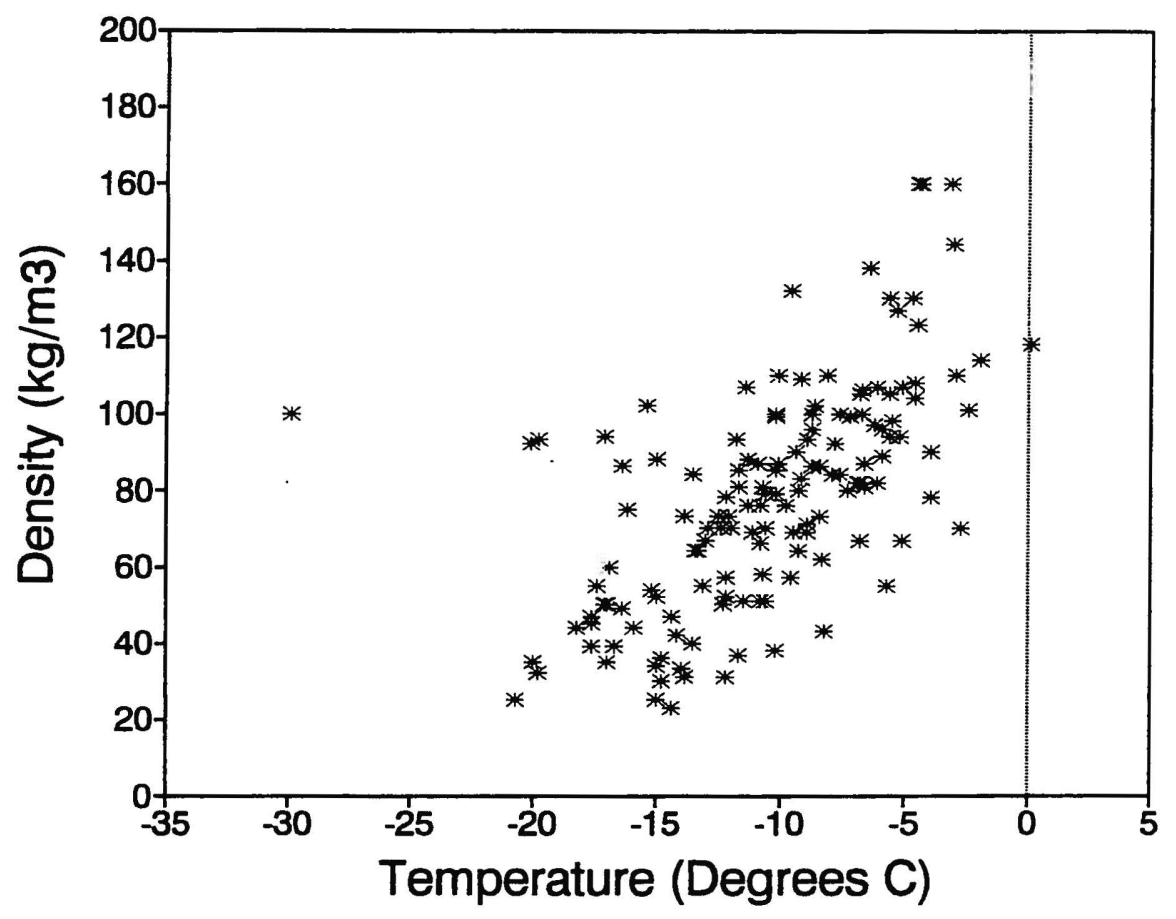

Figure 5. Daily new snow densities at Dry Lake, $\mathrm{CO}$ as a function of temperature at Storm Peak Laboratory, winters 1994-95 through 1997-98. 


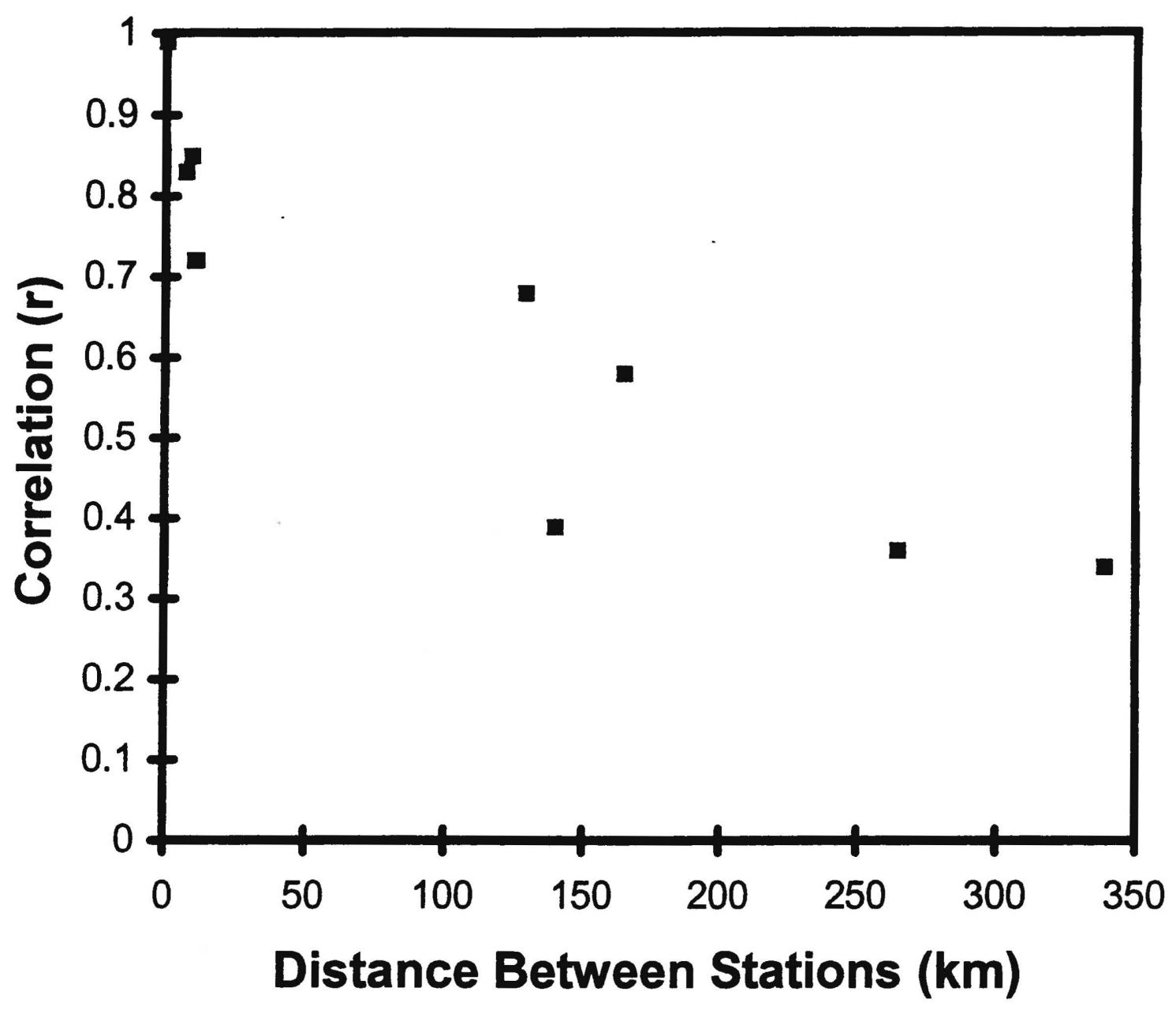

Figure 6. Correlation coefficient $r$ for synchronous daily observed snow densities as a function of distance between density measurement sites. 
A.

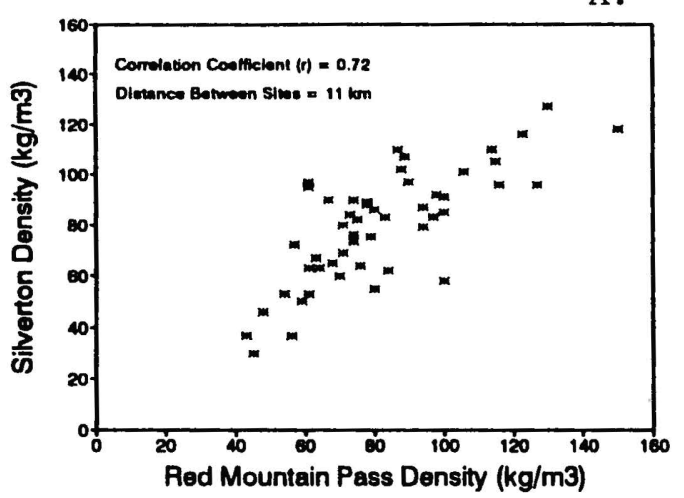

D.

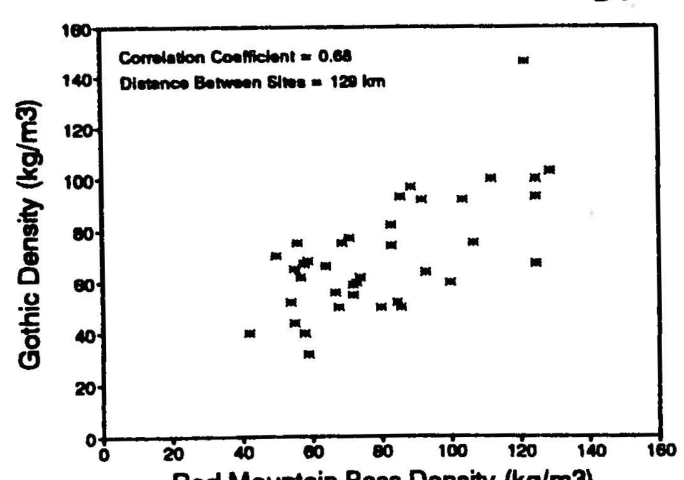

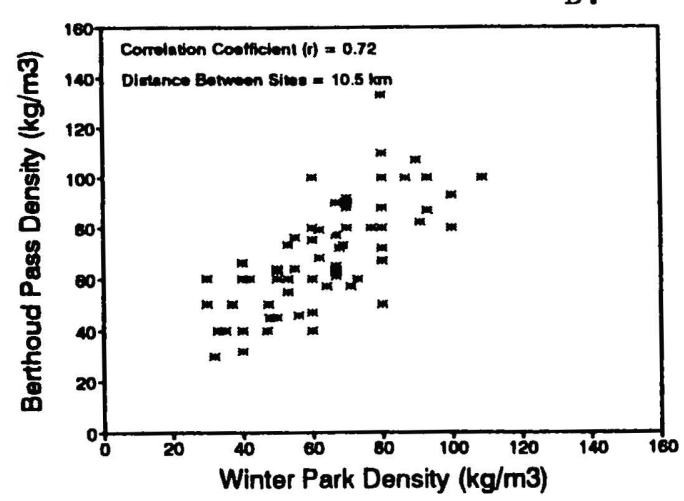

E.

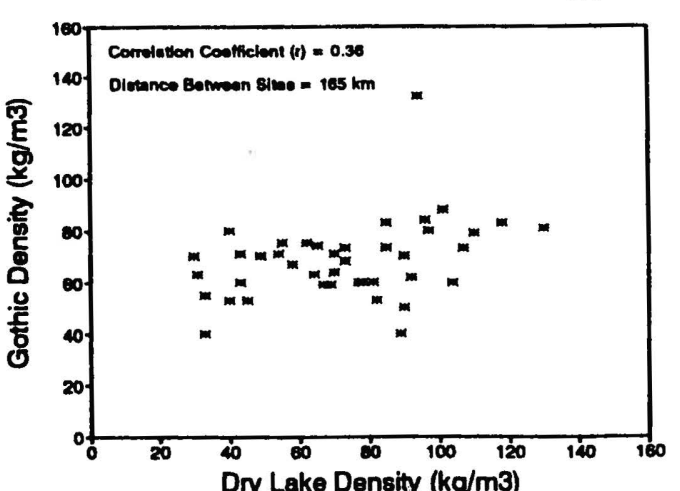

C.

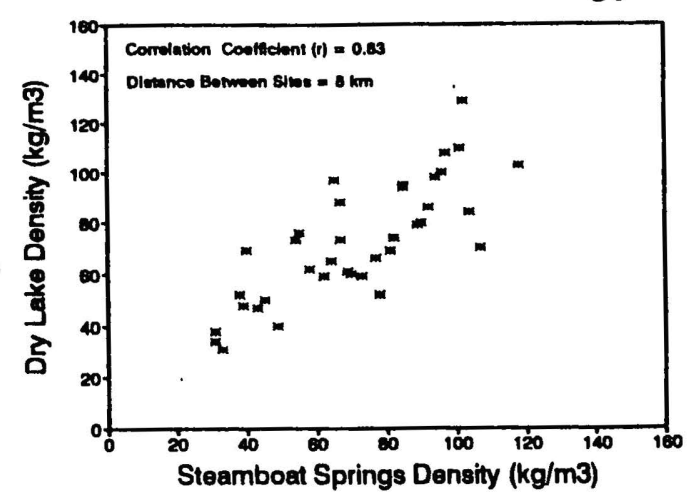

F.

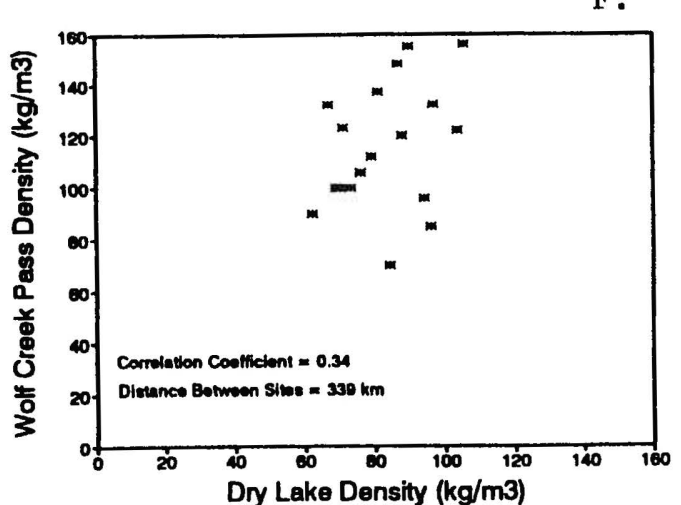

Figure 7. Interstation snow density scattergrams. 


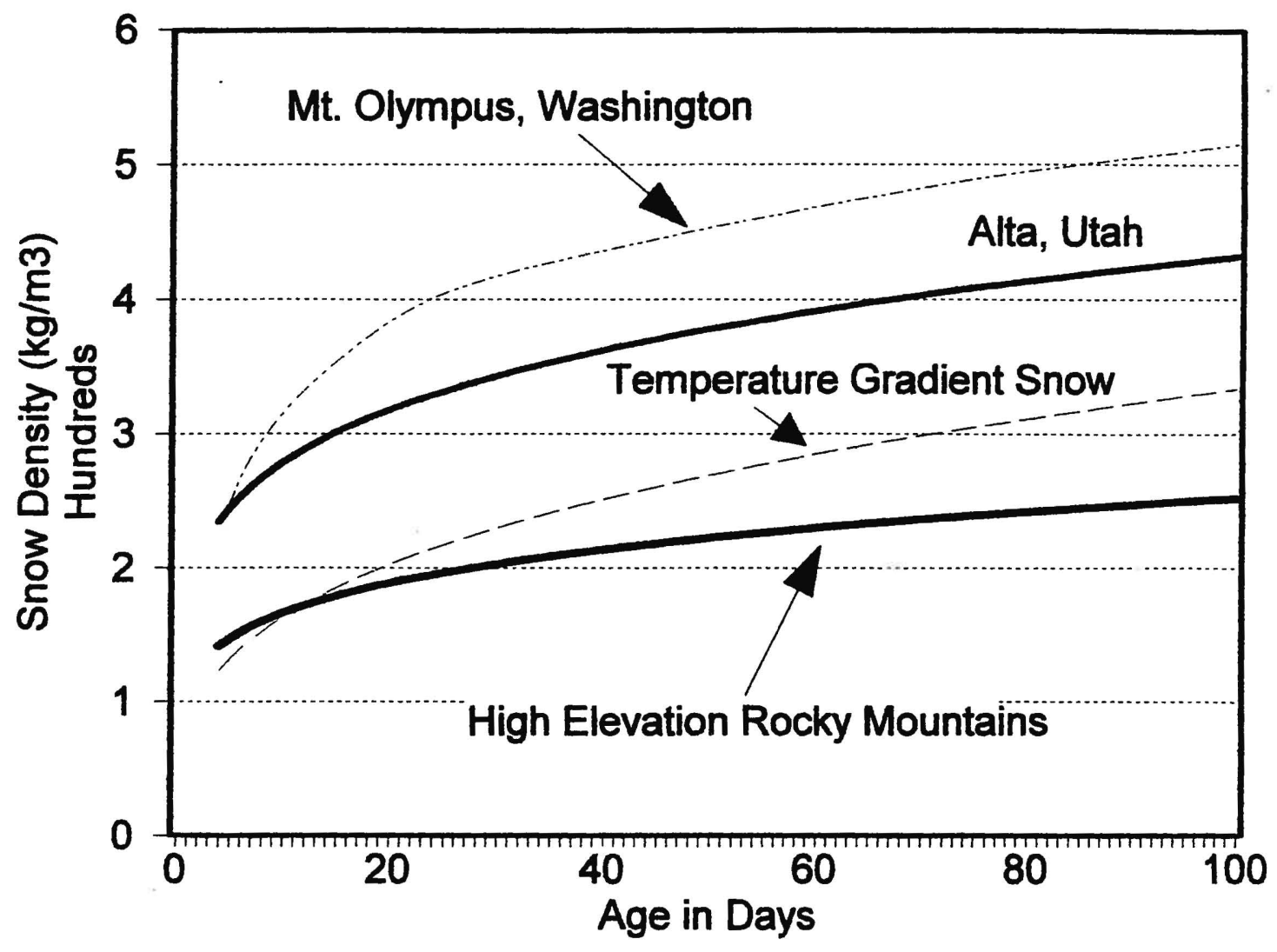

Figure 8. Mean layer density for existing cold snowpacks as a function of age in the first 100 days. 